\title{
STATED PREFERENCES FOR IMPROVED AIR QUALITY MANAGEMENT IN THE CITY OF NAIROBI, KENYA
}

\author{
Hilary Ndambiri ${ }^{1}$, Eric Mungatana ${ }^{1}$, Roy Brouwer ${ }^{2}$ \\ ${ }^{1}$ Center for Environmental Economics and Policy in Africa, \\ University of Pretoria, South Africa \\ ${ }^{2}$ Department of Environmental Economics, Institute for Environmental Studies, \\ Vrije University, Amsterdam, The Netherlands
}

\begin{abstract}
:
The study uses contingent valuation (CV) framework to assess individuals' preferences for improved air quality management through motorized emission reductions in the city of Nairobi, Kenya. A conventional payment card (PC) is used to draw preferences from individuals in order to estimate the mean and the median willingness to pay (WTP) for air quality improvements in the city. Through interval regression analysis, the study finds that individuals are, on average, willing to pay Kshs. 396.57 (\$4.67) and a median of Kshs. 244.94 (\$2.88) to improve air quality management in the city. These amounts are found to increase with male gender, individuals' income, certainty about future income and residence in an urban area. These amounts, however, decline with age, residential distance from nearby roads, and motor vehicle ownership. On the whole, the study shows significant public support towards improved air quality management in the city, which is of vital importance for effective formation and implementation of air quality management programmes.
\end{abstract}

\section{Key words:}

contingent valuation,

willingness to pay,

payment card,

air quality,

Nairobi.

\section{INTRODUCTION}

The continuous upsurge in the number of motor vehicles in most urban areas worldwide has raised enormous concerns over the effects of motor vehicle emissions on air quality of urban environments (Cadle et al., 2004; Gwilliam, 2003; Lilley, 2000). Although most transportation modes emit pollutants into the atmosphere through combustion of liquid fossil fuel, the relative abundance of pollutants varies depending on the exact composition of the fuel and details of combustion conditions (Cadle et al., 2004; Colvile et al., 2001). Some of the leading motorized emissions by mass include carbon monoxide (CO), nitrogen oxides $\left(\mathrm{NO}_{\mathrm{x}}\right)$, sulphur oxides $\left(\mathrm{SO}_{\mathrm{x}}\right)$, volatile organic compounds (VOCs) and the particulate matter $\left(\mathrm{PM}_{\mathrm{x}}\right)$ (Asian Development Bank, 2003; Colvile et al., 2001; Fazal, 2006; Schwela, 2004). These emissions are largely harmless if they are in low concentrations, but harmful if their concentrations escalate to levels that cause adverse effects on humans and the environment (Ababio, 2003; Amin, 2009). Furthermore, they are mostly ground level sources of pollution highly capable of rendering maximum impact on the general population (Ackerman et al., 2002; Gwilliam \& Johnson, 2004; Schwela, 2004; Vliet \& Kinney, 2007).

In the city of Nairobi, the growth of motorized traffic has been singled out as the major source of low air quality since motorized emissions account for about $90 \%$ of total emissions (Odhiambo et al., 2010; Omwenga, 2011). Toxic gases such as $\mathrm{CO}, \mathrm{NO}_{\mathrm{x}}$, $\mathrm{SO}_{\mathrm{x}}$ and $\mathrm{PM}_{\mathrm{x}}$ are in high concentrations as a result of increased urban expansion and motorization linked to rapid economic development experienced over the last decade. Consequently, most city residents are exposed to elevated concentrations of vehicular emissions that potentially pose serious long-term effects on human health and quality of the urban environment (Odhiambo et al., 2010; Kinney et al., 2011; Vliet \& Kinney, 2007). For instance, CO causes blood clotting 
when it reacts with haemoglobin. $\mathrm{PM}_{\mathrm{x}}$ are carcinogenic, especially those that penetrate deep into the lungs. Exposure to $\mathrm{NO}_{\mathrm{x}}$ leads to shortness of breath, chest pain and changes in lung function, while $\mathrm{SO}_{x}$ causes cardiovascular diseases and bronchitis with detrimental effects to asthmatics (WHO, 2006).

Notwithstanding these effects, the authorities in the city of Nairobi are yet to formulate a policy that averts any potential risk from motorized emissions, given that the city has resident and daytime population of 3.1 and 4.2 million people, respectively. The reason behind this problem is that the current studies on air quality in Nairobi (Kinney et al., 2011; Mulaku \& Kariuki, 2001; Odhiambo et al., 2010; Vliet \& Kinney, 2007) deal only with the technical aspects of measuring air pollutant concentrations. This implies that available policy information is only limited to technical aspects, while sufficient knowledge on the socioeconomic aspects of the policy is also needed for the effective air quality management. Therefore, the purpose of this study is to provide the missing policy information by assessing peoples' preferences towards improved air quality management in the city of Nairobi.

In both developed and developing countries, several studies have already been undertaken to estimate individuals' preferences for air quality improvements. For instance, Carlsson and Johansson-Stenman (2000) estimate individuals' preferences for air quality improvement in Sweden using the open-ended question format. They find that individuals are, on average, willing to pay about 2000 SEK/year. The WTP amounts are found to increase with respondents' income, wealth and education. They are larger for males, people owning a house, people living in more polluted areas and members of environmental organizations, but smaller for the retired people. In Manila, Philippines, Fabian and Vergel (2002), double-bounded discrete choice format is used to estimate commuters' preferences for improved air quality from public transport vehicles. They show that respondents are willing to pay for an increase in fare by as much as $\mathrm{PhP} 1.24$.

In Poland, Dziegielewska and Mendelsohn (2005) employ a system of dichotomous choice questions to analyze preferences of Polish citizens towards harmonization of Polish air pollution standards with the European Union (EU) standards. They reveal that Polish citizens value the benefits of managing pollution much less than other citizens from richer EU nations, which means that the suspension of the harmonization process seemed critical and needed to be based on the nations' economic prosperity. Wang et al. (2006) use an open-ended question format to estimate peoples' preferences for improved air quality in the urban areas of Beijing. They find that people are, on average, willing to pay $143 \mathrm{CNY}$ per household per year. The WTP is found to be an increasing function of income and education level, but a decreasing function of age and household population. It is larger for residents in the urban areas than for those in the suburbs.

Wang and Zang (2008) evaluate peoples' preferences for improved air quality based on a variety of hypothetical open-ended questions in Ji'nan, China. They reveal that $59.7 \%$ of respondents are, on average, WTP (willing to pay) 100 Chinese Yuan (CNY) per person per annum. Significant factors are found to influence individuals WTP (willingness to pay): expenditure incurred while treating respiratory diseases, individual's income and the number of workers in the family. In Mashhad, Iran, Firoozzarea and Ghorbani (2011) use open-ended questions and the Heckman procedure to estimate peoples' preferences for air pollution reduction together with the respective determinants. They find that the total monetary value of air quality improvement in highly polluted region is higher (7.134 billion Rials per month) than in the middle-polluted region (5.242 billion Rials per month). Age, number of children, gender, household income, education level and car owning are significant factors for people who are willing to pay (WTP) for improved air quality.

In addition, Du and Mendelsohn (2011) use the double-bounded valuation format with a single follow-up question to evaluate the preferences of Beijing residents to sustain the improved quality of air experienced during the Beijing Olympic Games. The results show that the mean annual WTP per household ranges between CNY 22,000 and 24,000. Finally, Donfouet et al. (2013) analyze peoples' preferences for air quality improvements in Douala, Cameroon, through a hypothetical referendum scenario. Respondents are also given an overnight time to think about their responses to the valuation questions. The results show that people are, on average, willing to pay (WTP) \$US 0.40 per month for improved air quality, which is about $0.02 \%$ of their annual income. The overnight time-to-think is found to have negative effects on individuals' valuation decisions since it lowered the WTP values by $40 \%$.

Except for China and Cameroon in the African context, the number of socioeconomic studies dealing with the issues of improved air quality management is insufficient. Such studies, if undertaken, may provide important policy information for addressing air 
quality issues, especially among rapidly urbanizing cities in the developing world. This study, therefore, seeks such policy information by analyzing peoples' preferences for improved air quality management in the city of Nairobi, Kenya.

The rest of the paper is structured as follows: Section 2 presents the theoretical framework, Section 3 describes the survey methodology, Section 4 presents the empirical results and discussion, and Section 5 offers the final conclusion.

\section{THEORETICAL FRAMEWORK}

Most empirical studies on peoples' preferences for air quality improvement have previously been conducted using non-market valuation methods. The use of non-market valuation methods has been justified because air quality is an environmental public good, hence unpriced and with no established market for its trading (Du \& Mendelsohn, 2011; Wang et al., 2006; Wang \& Mullay, 2003; Wang \& Whittington, 2005; Wang \& Zang, 2008). These methods are broadly classified into two groups (Mendelsohn \& Olmstead, 2009; Mitchell \& Carson, 1989):

a) the revealed preference methods (e.g. travel cost and hedonic pricing) and

b) stated preference methods (e.g. contingent valuation and choice experiments).

Under the revealed preference methods, proxy markets are used indirectly to attach monetary values on policy proposals by finding correlation between the real market behaviour of individuals and the policy proposal in question. Under stated preference methods, however, hypothetical markets are used directly to attach monetary values on policy proposals by asking people about their WTP for a policy proposal that enhances their welfare or willingness to accept (WTA) compensation for a proposal that decreases their welfare.

An important limitation of the revealed preference methods is that they can only attach monetary values on policy proposals through observation of real market transactions. In cases where it is impossible to observe real market transactions, the stated preference methods are preferred (Bateman et al., 2002; Venkatachalam, 2004; White et al., 2001). For that reason, this study implemented contingent valuation framework to assess peoples' preferences for improved air quality management in the city of Nairobi since real market transactions for air quality improvements are unavailable and can only be proxied through contingent valuation. Moreover, this framework was preferred over the choice experiment approach as it provides the total (use and nonuse) value of the policy proposals in question (Carson, 2000; Mitchel \& Carson, 1989).

Contingent valuation methodology is deeply rooted in the neo-classical welfare economic theory of consumer behaviour on expenditure minimization (Freeman, 1993; Mitchell \& Carson, 1989). In this case, consider the following general expenditure function for an individual living in the City of Nairobi:

$$
e(p, q, u)=y
$$

where $\mathrm{p}$ is a price vector, $\mathrm{q}$ is the quality of air in the city, $u$ is the level of utility, and $y$ is the minimum income necessary to allow an individual to maintain utility level in the city. Furthermore, consider the situation where a policy is proposed to improve air quality management through motorized emission reductions. The policy, thus, outlaws all activities that are detrimental to air quality. The individual is then asked about the amount he/she would be willing to pay to reduce motorized emissions. The expenditure function for the initial period before the proposed policy would be:

$$
e\left(p, q_{0}, u_{0}\right)=y_{0}
$$

where $u_{o}$ is the initial level of utility that an individual can enjoy given prices $p, q_{0}$ is the initial level of air quality in the city and $y_{o}$ represents the minimum level of income required to attain utility level $u_{o}$. Since the new policy is expected to improve air quality in the city, the new expenditure function would, therefore, be of the form:

$$
e\left(p, q_{1}, u_{0}\right)=y_{1}
$$

where $\mathrm{q}_{1}$ is the quality of air after the implementation of the proposed policy and $y_{1}$ represents the minimum income level required to attain utility level $\mathrm{u}_{\mathrm{o}}$ after the implementation of the proposed policy. The level of utility, $u_{\mathrm{o}}$, is held constant since Hicksian welfare measures assume that utility remains constant. Hence, the individual's WTP for improved air quality would be a compensating variation measure since an individual would have to part with a certain amount for the improvement to occur. The compensating variation $(\mathrm{C})$ is equal to the individual's WTP and is given by difference between the expenditure functions $\mathrm{y}_{1}$ and $\mathrm{y}_{0}$ : 


$$
\begin{aligned}
& C=W T P=y_{1}-y_{o} \\
& C=\left\{e\left(p, q_{1}, u_{o}\right)-e\left(p, q_{0}, u_{o}\right)\right\}
\end{aligned}
$$

The quality of air in the city upon implementing the proposed policy, $\mathrm{q}_{1}$, is supposedly greater than the initial air quality, $\mathrm{q}_{0}$. As utility and prices are held constant, $\mathrm{y}_{1}$ (the minimum income level required to attain utility level $u_{o}$ after implementation of the proposed policy) is less than $\mathrm{y}_{0}$. Therefore, the compensating variation would be negative meaning that an individual has to pay some dollar amount to attain the improved level of air quality management.

\section{SURVEY DESIGN}

\section{The study area}

The city of Nairobi is located at the south-eastern end of Kenya's agricultural heartland, at approximately $1^{\circ} 9^{\prime} \mathrm{S}, 1^{\circ} 28^{\prime} \mathrm{S}$ and $36^{\circ} 4^{\prime} \mathrm{E}, 37^{\circ} 10^{\prime} \mathrm{E}$. It has eight administrative divisions occupying an area of about $696 \mathrm{~km}^{2}$ with an altitude that varies between 1,600 and 1,850 metres above sea level. Although the city covers only 0.1 per cent of Kenya's total surface area, it carries about 8 per cent of the country's total population and about 25 per cent of Kenya's urban population (CBS, 2009). Due to high population growth, the demand for transport in the city has been on the rise, which has resulted in increased motorization and hence, unprecedented levels of vehicle emissions.

\section{Population and sample}

The city's resident population is estimated at 3.1 million people (CBS, 2009) spread over eight administrative divisions. As such, simple random sampling was used to select 61 respondents from each of the eight administrative divisions constituting the city of Nairobi to make an overall sample of 488 respondents for the entire study. This sampling procedure was chosen because it offered all city residents an equal chance to be part of the study sample. Subsequently, the survey data was collected from each of the administrative divisions, as they could conceptually be regarded as separate populations upon which interviews could be performed independently.

\section{Survey technique}

The study employed personal interviews based on interviewer administered questionnaires to collect in- formation from respondents. This method was chosen because it could enable the interviewer to motivate respondents to fully participate in the interview process, probe unclear responses and convey intricate information on the study subject to the respondents (Arrow et al., 1993; Dillman, 2000).

The questionnaire was divided into five sections, namely:

a) a background section that sought respondents' general knowledge of air pollution in Nairobi;

b) a section describing the motorized emission reduction plan;

c) a section describing both positive and negative effects of the motorized emission reduction plan;

d) a section with the valuation and debriefing questions and;

e) a section that sought information on respondents' socio-demographic characteristics.

\section{Survey implementation}

A pre-test survey was conducted on the survey questionnaire on a sample of thirty respondents using the open-ended value elicitation format as recommended in Haab and McConnell (2002). The respondents were asked to comment on suitability of questions in the questionnaire, paying close attention to wording, clarity, relevance and interpretation of each question in the survey among other anomalies. Bid ranges were also obtained from the pre-test, from which the mean, median, minimum and the maximum WTP values were determined. Based on the responses and comments provided by the respondents in the exercise, a final survey questionnaire was prepared and administered to 488 respondents.

\section{Considered environmental good}

A policy proposal for improved air quality management through motorized emission reductions in Nairobi constituted the public good of interest that was valued in the study. Notably, motorized emissions differ enormously from one vehicle to another, such that an accurate description of some definite level of emission reduction is difficult and can be misleading. As a result, a valuation question that sought for an overall reduction of motorized emissions in the city was posed to respondents and the values they gave were used to estimate mean and median WTP values for the study sample. 


\section{Payment vehicle}

Popular payment vehicles used by researchers in $\mathrm{CV}$ include fees, taxes and amenity bills. However, Morrison et al. (2000) note that some of these payment vehicles can raise objections and protest responses among survey participants and hence bias the survey results. Following Fonta et al. (2010), this study uses a special trust fund, a neutral kind of payment vehicle, so as to minimize objections and protest responses among participants. In this fund, respondents were hypothetically required to make a one-time contribution to the exclusive purpose of reducing motorized emissions. It was expected that the payment vehicle would enhance the credibility of the hypothetical scenario as opposed to other alternative payment vehicles such as fees, taxes or amenity bills often linked with protest responses in contingent valuation (Morrison et al., 2000; Sayadi et al., 2009).

\section{Valuation format}

The study used the PC format to elicit individuals' preferences based on a comprehensive policy proposal that would control motorized emissions in the city of Nairobi. Under this format, the respondents were given cards where they were asked to circle the highest amount they would be willing to pay for the emission reductions. Out of the responses given, inferences were made about their true WTP, which was equal to or higher than the circled value but lower than the next higher value (Cameron \& Huppert, 1989). This format was chosen because of the fact that the respondents had the advantage to easily and visually scan through the given set of value intervals (Cameron \& Huppert, 1989) and hence determine the range of their WTP. Furthermore, the kind of data obtained through this format is less scattered and, therefore, does not require larger samples to obtain robust estimates. The format does not suffer from yeah-saying and starting point bias like other contingent valuation formats (Mitchell \& Carson, 1993). Although PC questions are theoretically susceptible to range and mid-point bias, there is little empirical evidence of the existence of range or mid-point bias (Klose, 1999; Ryan et al., 2004). Even though the format still has the possibility of yielding protest zeros, it has not been found to give very high proportion of protest zero responses compared to other contingent valuation formats (Hanley et al., 2003; Klose, 1999).
Thus, the valuation question was formulated as follows: "Suppose the presented policy to reduce emissions from motorized vehicles and improve air quality management in the city of Nairobi will actually be implemented to reduce the current amount of emissions, what is the maximum amount of money you would be willing to pay one-off to the special trust fund to achieve this? (circle or tick a single amount on the card)."

The PC included 15 different dollar amounts, namely: Kshs. 0, 25, 50, 75, 100, 150, 200, 250, 300, $400,500,800,1000,1500$ and finally Kshs. 2,000, in which case respondents were only required to circle one single amount on the card.

\section{Estimation method}

Following Cameron and Huppert (1989), the interval regression analysis was used to estimate the mean and median WTP values from responses generated through the PC format. Letting $\mathrm{WTP}_{\mathrm{L}}$ be the maximum amount that a respondent would pay and $\mathrm{WTP}_{\mathrm{U}}$ be the lowest amount that a respondent would switch to a 'No' rather than a 'Yes' response, the individuals' WTP is therefore taken to lie somewhere in the switching interval $\left(\mathrm{WTP}_{\mathrm{L}}, \mathrm{WTP}_{\mathrm{U}}\right)$. In order to adjust for the skewed distribution of WTP responses, the lognormal transformation of the WTP responses is preferred, hence:

$$
\log W T P_{i}=g_{i}^{\prime} \varpi+\xi_{i}
$$

where $\mathrm{g}_{\mathrm{i}}$ denotes the characteristics of the respondent or the valuation good in question, $\xi_{i}$ stands for the normally distributed random variable with zero mean and standard deviation $\sigma$, and $\varpi$ are regression coefficients. Assuming that WTP is a random variable (Welsh \& Poe, 1998), the probability that a respondent would select a given monetary amount is:

$$
\begin{aligned}
& \operatorname{Prob}(\text { yes })=\operatorname{prob}\left(W T P_{i} \geq W T P_{L}\right) \\
& \operatorname{Prob}(\text { yes })=1-Q_{W T P}\left(W T P_{L}\right)
\end{aligned}
$$

where $\mathrm{Q}_{\mathrm{WTP}}\left(\mathrm{WTP}_{\mathrm{L}}\right)$ is the cumulative distribution function of the random WTP variable. The probability that the WTP would fall between any two monetary thresholds is:

$$
\operatorname{Prob}\left(W T P_{U}>W T P_{i} \geq W T P_{L}\right)=Q_{W T P}\left(W T P_{U}\right)-Q_{W T P}\left(W T P_{L}\right)
$$

which results in the corresponding log-likelihood function for $\mathrm{n}$ number of respondents as:

$$
\log (L)=\sum_{i=1}^{n} \log \left\{Q_{W T P}\left(\frac{W T P_{U}-\varpi g_{i}^{\prime}}{\sigma}\right)-Q_{W T P}\left(\frac{W T P_{L}-\varpi g_{i}^{\prime}}{\sigma}\right)\right\}
$$


With further assumption that the stochastic term is normally distributed, $\varpi$ and $\sigma$ can be estimated and then used to compute the mean and median WTP values. Thus, the mean WTP $=\mathrm{e}^{\left(g_{i} \omega+\sigma^{2} / 2\right)}$ and median WTP $=\mathrm{e}^{\left(g_{i} \varpi\right)}$. Here, $\mathrm{g}^{\prime}$ is taken as the vector of mean values of explanatory variables, $\varpi$ as the vector of estimated coefficients and $\sigma$ as the estimated standard variance.

\section{RESULTS AND DISCUSSION}

\section{Socio-demographic characteristics of respondents}

Table 1 presents the socio-demographic characteristics of respondents. As shown, the average age of respondents is between 31-40 years with men accounting for the largest share (62\%) of respondents. A large proportion of respondents has attained secondary level of education and has an average household size of about 3 people. The mean annual income of respondents varies between Kshs. 20,000 (\$253.29) - 30,000 (\$352.94) with a large section of the respondents $(83 \%)$ indicating that they were certain about their future incomes. Research results also show that most respondents resided close (150-200 metres) to nearby roads with a large share living in the urban areas $(69 \%)$ as opposed to the suburbs (31\%). Only a minority of respondents (18\%) said they owned a motor vehicle.
Further results also show that people in Nairobi are familiar with air pollution problem, even though they may interpret it differently. While $88 \%$ of the respondents define it as the contamination of air with smoke and dust particles, $12 \%$ perceive it as bad odour from rotting waste and smoke. Regarding the main sources of air pollution, 55\% of respondents mention motor vehicles as the main source of air pollution followed by factories (25\%), burning of waste by households (19\%) and finally, farming activities (5\%). Serious problems that respondents associated with air pollution are respiratory in nature (71\%), due to bad odour, dust particles and vehicular smoke. Despite these concerns from the public, the concerned authorities have still done little to address this issue. As a result, some policy measures recommended by the respondents to contain the situation include the use of: quality fuels (51\%); fuel efficient motorized vehicles (18\%); improved road infrastructure (13\%); traffic regulation and control (12\%) and construction of bicycle lanes to enhance the use of bicycles (1\%). It is found that the majority of respondents (62\%) prefer the use of a special fund as the payment vehicle to support their proposed strategies as opposed to donating their labour (17\%), being charged a pollution tax (15\%) or the use of amenity bills (6\%). As such, the use of the special trust fund in the study is found to be widely accepted among respondents.

\begin{tabular}{|c|c|c|c|c|c|c|}
\hline Variable & Variable description and type & Mean & $\begin{array}{l}\text { Std. } \\
\text { error }\end{array}$ & Min & Max & Sign \\
\hline Age & $\begin{array}{l}\text { Age of the respondent in years (categorical: } 1=<20 ; 2=20-30 \\
3=31-40 ; 4=41-50 ; 5=51-60 ; 6=\text { above } 60 \text { ) }\end{array}$ & 3.04 & 0.05 & 1 & 6 & \pm \\
\hline Gender & $\begin{array}{l}\text { Gender of the respondent (dummy variable: } 1=\text { male; } 0=\text { oth- } \\
\text { erwise). }\end{array}$ & 0.62 & 0.02 & 0 & 1 & + \\
\hline Education & $\begin{array}{l}\text { Education of the respondent (categorical: } 1=\text { no education; } \\
2=\text { standard; } 3=\text { secondary; } 4=\text { tertiary; } 5=\text { university). }\end{array}$ & 3.61 & 0.05 & 1 & 5 & + \\
\hline $\begin{array}{l}\text { Household } \\
\text { income }\end{array}$ & $\begin{array}{l}\text { Average annual earnings in Kshs. (categorical: } 1=<10,000 \\
2=10,001-20,000 ; 3=20,001-30,000 ; 4=30,001-40,000 \\
5=40,001-50,000 ; 6=50,001-60,000 ; 6=\text { above } 60,000 \text { ) }\end{array}$ & 2.86 & 0.07 & 1 & 6 & + \\
\hline $\begin{array}{l}\text { Household } \\
\text { size }\end{array}$ & $\begin{array}{l}\text { Number of family members in the household (categorical: } \\
1=1 ; 2=2 ; 3=3 ; 4=4 ; 5=5 ; 6=\text { above } 5 \text { members). }\end{array}$ & 3.49 & 0.06 & 1 & 6 & - \\
\hline $\begin{array}{l}\text { Distance to } \\
\text { nearby roads }\end{array}$ & $\begin{array}{l}\text { Distance from nearby road in meters (categorical: } 1=<50 ; \\
2=51-100 ; 3=101-150 ; 4=151-200 ; 5=201-250 ; 6=\text { above } 251 \text { ). }\end{array}$ & 4.78 & 0.08 & 1 & 6 & - \\
\hline $\begin{array}{l}\text { Vehicle } \\
\text { ownership }\end{array}$ & $\begin{array}{l}\text { Whether or not the respondent owns a vehicle (dummy vari- } \\
\text { able: } 1=\text { own; } 0=\text { otherwise). }\end{array}$ & 0.18 & 0.02 & 0 & 1 & - \\
\hline $\begin{array}{l}\text { Future } \\
\text { income } \\
\text { certainty }\end{array}$ & $\begin{array}{l}\text { Whether or not the respondent is certain about future in- } \\
\text { comes (dummy variable: } 1=\text { certain; } 0=\text { otherwise). }\end{array}$ & 0.83 & 0.02 & 0 & 1 & + \\
\hline $\begin{array}{l}\text { Area of } \\
\text { residence }\end{array}$ & $\begin{array}{l}\text { Whether or not the respondent resides in the urban area or } \\
\text { in the suburbs (dummy variable: } 1=\text { urban; } 0=\text { otherwise). }\end{array}$ & 0.69 & 0.02 & 0 & 1 & + \\
\hline
\end{tabular}

Table 1. Socio-demographic characteristics of the respondents and their measurement 
Table 2 presents the analysis of various types of WTP responses derived from the study. The survey included a total of 488 respondents. Out of the total number, about 417 respondents (85\%) indicated a positive WTP for motorized emission reductions and 71 respondents (15\%) gave a zero WTP value. In order to separate protest responses from true zeroes, a closed-ended debriefing question was presented to respondents to justify why they had a zero WTP for air quality improvements. Thus, four possible alternatives were presented to respondents, namely: a) because air quality improvement has no value to me, $b$ ) because it is the responsibility of the government, c) because of many other basic financial commitments and, $d$ ) because it is the responsibility of motor vehicle owners.

\begin{tabular}{lcc}
\hline \multicolumn{1}{c}{ WTP Responses } & Frequency & $\%$ \\
\hline $\begin{array}{l}\text { Positive willingness to pay } \\
\text { responses }\end{array}$ & 417 & 85 \\
\hline $\begin{array}{l}\text { True zero willingness to } \\
\text { pay responses }\end{array}$ & 18 & 4 \\
\hline Analytical sample size & 435 & 89 \\
\hline Protest responses & 53 & 11 \\
\hline Total sample size & 488 & 100 \\
\hline
\end{tabular}

Table 2. Summary of willingness to pay responses

Following Strazzera et al. (2003), the first (a) and the third (c) responses were classified as true zero values, while the other two as protest responses since they did not address the value of the public good in question, but some objection as to who should really pay for air quality improvements. Based on the above-given classification, 18 respondents (4\%) gave a true zero WTP value, while 53 (11\%) gave a protest response. In line with the standard practice in valuation studies (Brouwer, 2009; Wang, 1997; Wang \& Whittington, 2000; Whitehead et al., 1998), the protest responses were excluded from the analysis. Therefore, only 435 responses, i.e., about $89 \%$ of the initial sample size, were subjected to further analysis.

Figure 1 presents different bid amounts used in the study together with the responses against each bid amount. Out of the 15 bids presented, respondents were supposed to indicate their maximum WTP for air quality improvements in Nairobi. The bids were truncated from below at Kshs. 0 and from above at Kshs. 2,000. As shown in the table, 18 (4\%) respondents state a maximum WTP of Kshs. 0, while 4 (1\%) respondents state Kshs. 1,500. On the whole, most respondents state Kshs. 500 (14\%), Kshs. 100 (13\%), Kshs. 200 (9\%) and Kshs. 400 (8\%) as their individual maximum WTP.

\section{Mean willingness to pay and the determinant factors}

As shown in Table 3, the study found that respondents are, on average, willing to pay Kshs. 396.57 (\$4.67) with a median value of Kshs. 244.94 (\$2.88) to improve air quality management in the city. In order to assess the factors influencing individuals WTP, several sociodemographic characteristics of respondents, namely, age, gender, income, distance resided by respondents from a nearby road, motor vehicle ownership, respondents certainty about future income and area of residence, were regressed against the grouped data on WTP. Further results of the interval regression analysis are shown in Table 3.

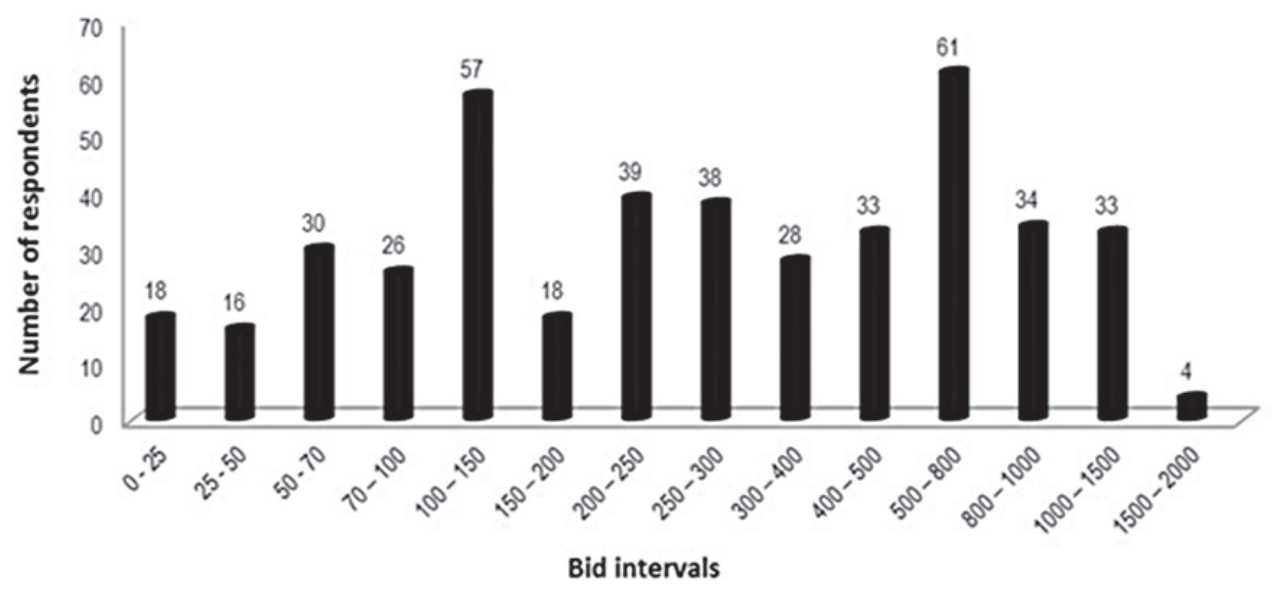

Figure 1. The distribution of willingness to pay responses 


\begin{tabular}{lcc}
\hline \multicolumn{1}{c}{ Variable } & Coefficient & Std. errors \\
\hline Age & $-0.118^{* * *}$ & 0.011 \\
\hline Gender & $0.375^{* * *}$ & 0.028 \\
\hline Household income & $0.531^{* * *}$ & 0.052 \\
\hline Distance to nearby road & -0.020 & 0.272 \\
\hline Vehicle ownership & $-0.192^{*}$ & 0.043 \\
\hline $\begin{array}{l}\text { Certainty of future } \\
\text { income }\end{array}$ & $0.196^{*}$ & 0.034 \\
\hline Area of residence & $0.442^{*}$ & 0.075 \\
\hline Constant & $3.872^{* * *}$ & 0.221 \\
\hline
\end{tabular}

\begin{tabular}{lc}
\hline Log likelihood & -994.21 \\
\hline Number of observations & 435 \\
\hline LR chi2 (7) & 280.17 \\
\hline Probability $>$ chi2 & 0.0000 \\
\hline
\end{tabular}

\begin{tabular}{lc}
\hline Mean WTP (in Kshs.) & 396.57 \\
\hline Standard error & 17.06 \\
\hline Median WTP (in Kshs.) & 244.94 \\
\hline $\begin{array}{l}\text { Bootstrapped 95\% confi- } \\
\text { dence intervals }\end{array}$ & $361.11-432.03$ \\
\hline
\end{tabular}

Note: $* * *$ and $* * *$ denote $\mathrm{p}<0.1, \mathrm{p}<0.05$ and $\mathrm{p}<0.01$.

Table 3. Interval regression results on factors explaining individual's willingness to pay

As indicated in Table 1, it was hypothesized that age of respondents would either have positive or negative relationship with the individuals' WTP. This is because older people may sometimes feel susceptible to the effects of motorized emissions and, therefore, are more willing to pay than younger people. Older people may, on the other hand, have a lower WTP because of the trade-offs they may have to make within the household, such as paying school fees. However, the study results show the negative relationship between the age of respondents and their WTP, which implies that younger people are more willing to pay for improved air quality management than older people. These results are similar to those by Carlson and Johansson-Stenman (2000) and Wang et al. (2006), who claim that younger individuals would pay more for air quality improvement plans than older individuals. However, Wang and Mullay (2006) came up with the contrary findings.

Positive relationship between gender and the WTP was also hypothesized and the results came out as expected. It means that men are more willing to pay for improved air quality management than women. The most probable reason for this is the fact that men have more access to information than women and would therefore be more informed about the negative effects of vehicular emissions than women, together with the need for emission controls. Another reason is that they also control budgets within the household. This outcome correlates well with the similar outcome in Carlson and Johansson-Stenman (2000) and Wang and Zang (2008). Household income is another important variable used in the study to explain individuals' decisions to pay for improved air quality management. It was expected that individuals with higher incomes would be more willing to pay for emission reductions than those with lower incomes, which would conform to economic theory (Loomis \& Ekstrand, 1998). The results are positive and they theoretically validate the outcome of the study. A similar outcome is found in many other CV studies including Carlson and Johansson-Stenman (2000), Wang et al. (2006), Wang and Mullay (2006) and Wang and Zang (2008).

The distance variable was used to assess whether or not the WTP would vary with distance since the perceived effects of motorized emissions were likely to vary with distance from a nearby road. The findings give evidence of negative, though statistically insignificant relationship meaning that residents living closer to nearby roads are more willing to pay for improved air quality management than their counterparts residing further away from the road. This finding can be attributed to the fact that people residing closer to the road have the perception that they are more affected by emissions than their counterparts residing further away from roads and, therefore, are more willing to pay for air quality improvements. Studies by Carlson and Johansson-Stenman (2000) and Wang et al. (2006) also reveal similar findings that people living in high polluted areas are more willing to pay than those living in the low polluted areas.

Negative correlation was expected between motor vehicle ownership and the WTP, because of the public willingness to improve air quality. The results came out as expected as motor vehicle owners are found to be more willing to pay for air quality improvements than non-vehicle owners. However, the results differ from those by Firoozzarea and Ghorbani (2011) who found out that car owners are more willing to pay than non-car owners. Notably, the share of car owners in this study was quite low, which could partly explain why these results differ.

The study also examines whether or not individuals' certainty about their future incomes would have a positive effect on the WTP variable and, as predicted, 
it was found that individuals who are certain about their future incomes are more willing to pay than those with uncertain future incomes. Similar findings are also reported in Fonta et al. (2010). Finally, the study also reveals positive relationship between the area of residence and individuals' WTP. As in Wang et al. (2006), it means that urban residents are more willing to pay for improved air quality management than their counterparts in the suburbs.

\section{CONCLUSIONS}

This study is conducted with the aim to analyze individuals' preferences for improved air quality management through reduced motorized emissions in the city of Nairobi, Kenya, based on the responses from the contingent valuation PC format. The research was inspired by the need to estimate the policy value of implementing air quality improvement programme for the city of Nairobi since air quality problems were on the rise due to the rapid urbanization experienced over the last decade. Initial findings have shown that people in Nairobi are well aware of the air pollution problems in the city upon which they identify motor vehicles as the primary cause of air quality problems owing to the emission of toxic gases and dust particles into the atmosphere.

Nairobi residents have also been found to be familiar with adverse health and environment effects of motorized emissions and, as a result, most of them are willing to pay positive amounts towards emission reductions in the city. While a few people are willing to pay true zero amounts towards the same course citing overwhelming financial commitments within the household, others give protest responses against the air quality improvement plan, saying that the government and/or the motor vehicle owners should bear the responsibility of the air clean-up plans. In monetary terms, individuals in the study are, on average, willing to pay Kshs. 396.57 (\$4.67) for improved air quality management. The median WTP is Kshs. 244.94, which is equivalent to $\$ 2.88$. Moreover, age, gender, income, motor vehicle ownership, certainty about future income and the area of residence are found to have significant effects on peoples' WTP decision for air quality improvements.

Since air quality issues continue to worsen in Nairobi due to increased motorization, the city authorities can now use the estimated mean and median WTP to benchmark their budget and policy proposals for motorized emission reductions. Based on the study findings, these budget and policy proposals can also be adjusted to the socio-demographic characteristics of individuals, as they have been found to be important determinants of the peoples' WTP decision. The valuation estimates can also be used to determine the economic efficiency of other air quality improvement programmes in the city of Nairobi and beyond, since peoples' preferences are evident and determinate. All in all, more studies are required to further our understanding of the policy values of tackling specific issuess (e.g. respiratory diseases, damage to city buildings and contamination of the city water dam) that arise from motorized emissions. Such studies may provide varied additional information to decision makers on how to deal with different air quality problems in a developing country context.

Acknowledgements: This study was funded by the Center for Environmental Economics and Policy in Africa (CEEPA), University of Pretoria, the Republic of South Africa, and the Centre for International Cooperation (CIC), Vrije Universiteit Amsterdam, the Nethrelands.

\section{REFERENCES}

Ababio, O.Y. (2003). New school chemistry. Onitsha: Africana-FEP.

Ackerman, M., Davies, T., Jefferson, C., Longhust, J., \& Marquez, J. (2002). Comparison of diesel and hybrid vehicle emissions by computer modelling. Urban Transport, VIII, 471-480. doi:10.2495/UT020461.

Amin, A.T.M.N. (2009). Reducing emissions from private cars: Incentive measures for behavioural change. Nairobi, Kenya: UNEP. Retrieved Jun, 15, 2015, from http://www. unep.ch/etb/publications/Green\%20Economy/Reducing\%20emissions/UNEP\%20Reducing\%20emissions\%20 from $\% 20$ private $\% 20$ cars.pdf

Arrow, K., Solow, R., Portney, P.R., Leamer, E.E., \& Radner, R.H. (1993). Report on the NOAA Panel on contingent valuations, natural resource damage assessment under the Oil Pollution Act of 1990. Federal Register, 58, 46014614.

Asian Development Bank. (2003). Reducing vehicle emissions in Asia. Manila, Philippines: Asian Development Bank.

Bateman, I., Carson, R.T., Day, B., Hanemann, W.M., Hanley, N., \& Hett, T. (2002). Economic valuation with stated preferences: A Manual. Cheltenham, UK: Edward Elgar.

Brouwer, R. (2009). Stated preference uncertainty: signal or noise? Amsterdam: Institute for Environmental Studies, VU University Amsterdam.

Cadle, S.H., Croes, B.E., Minassian, F., Natarajan, M., Tierney, E.J., \& Lawson, D.R. (2004). Real-world vehicle emissions: A summary of the Thirteenth Coordinating Research Council on-road Vehicle Emissions Workshop. 
Journal of the Air and Waste Management Association, 54(1), 18-23.

Cameron, T.A., \& Huppert, D.D. (1989). OLS versus ML estimation of non-market resource values with payment card interval data. Journal of Environmental Economics and Management, 17(3), 230-246. doi:10.1016/00950696(89)90018-1.

Carlsson, F., \& Johansson-Stenman, O. (2000). Willingness to pay for improved air quality in Sweden. Journal of Applied Economics, 32(6), 661-669. doi:10.1080/000368400322273.

Carson, R.T. (2000). Contingent valuation: a user's guide. Environmental Science and Technology, 34(8), 1413-1418. doi:10.1021/es990728j.

Central Bureau of Statistics - CBS. (2009). Economic Survey 2009. Nairobi, Kenya: Central Bureau of Statistics (CBS).

Colvile, R.N., Hutchinson, E.J., Mindell, J.S., \& Warren, R.F. (2001). The transport sector as a source of air pollution. Atmospheric Environment, 35(9), 1537-1565. doi:10.1016/S1352-2310(00)00551-3.

Dillman, D.A. (2000). Mail and internet surveys: the tailored design method. New York: John Wiley \& Sons.

Donfouet, H., Cook, J., \& Jeanty, P.W. (2013). The economic value of improved air quality in urban Africa: results from Douala, Cameroon. Environment and Development Economics, 20(5), 630-649. doi:10.1017/S1355770X14000552.

Dziegielewska, D., \& Mendelsohn, R. (2005). Valuing air quality in Poland. Journal of Environmental and Resources Economics, 30(2), 131-163. doi:10.1007/s10640004-1515-2.

Fabian, H.G., \& Vergel, K.N. (2002). Analysis of air pollution exposure of individuals in the road environment. Journal of the Eastern Asia Society for Transportation Studies, 4(5), 55-70.

Fazal, S. (2006). Addressing congestion and transport-related air pollution in Saharanpur, India. Environment and Urbanization, 18(1), 141-154.

Firoozzarea, A., \& Ghorbani, M. (2011). Investigation of citizens' WTP for Mashhad air pollution reduction: applying Heckit model. 5th Symposium on Advances in Science \& Technology, Mashhad, Iran. Retrieved Jun, 15, 2015, from http://profdoc.um.ac.ir/articles/a/1022664.pdf

Fonta, M., Ichoku, H.E., \& Nwosu, E. (2010). Contingent valuation in community-based project planning: the case of Lake Bamendjim fishery restocking in Cameroon. African Economic Research Consortium, Nairobi, Research Paper 210. Retrieved Jun, 15, 2015, from https://www.africaportal.org/dspace/articles/contingent-valuation-communitybased-project-planning-case-lake-bamendjim-fishery

Foster, V., \& Mourato, S. (2003). Elicitation format and sensitivity to scope do contingent valuation and choice experiments give the same results? Environmental and Resource Economics, 24(2), 141-160. doi:10.1023/A:1022856329552.

Freeman, A.M. (1993). The measurement of environmental and resource values: theory and methods. Washington: Resources for the Future.
Gwilliam, K. (2003). Urban transport in developing countries. Transport Reviews, 23(2), 197-216. doi: 10.1080/01441640309893.

Gwilliam, K., Kojima, M., \& Johnson, T. (2004). Reducing air pollution from urban transport. Washington, DC: World Bank.

Haab, T.C., \& McConnell, K.E. (2002). Valuing Environmental and Natural Resources: the Econometrics of Nonmarket Valuation. Cheltenham, UK: Edward Elgar.

Hanley, N., Kriström, B., \& Shogren, J.F. (2009). Coherent arbitrariness: on value uncertainty for environmental goods. Land Economics, 85(1), 41-50. doi:10.3368/ le.85.1.41

Kinney, P.L., Gatari, M., Volavka-Close, N., Ngo, N., Ndiba, P.K., Law, A., Gachanja, A., Gaita, M.S., Chilrud, S.N., \& Sclar, E. (2011). Traffic impacts on $\mathrm{PM}_{2.5}$ air quality in Nairobi, Kenya. Environmental Science and Policy, 14(4), 369-378. doi:10.1016/j.envsci.2011.02.005.

Klose, T. (1999). The contingent valuation method in health care. Health Policy, 47(2), 97-123.

Lilley, L.C. (2000). A new approach to emissions inventory modelling - Assessing fuel and vehicle impacts on air quality. Advances in Air Pollution, 8, 389-398. doi:10.2495/AIR000391.

Loomis, J., \& Ekstrand, E. (1998). Alternative approaches for incorporating respondent uncertainty when estimating willingness to pay: The case of the Mexican spotted owl. Ecological Economics, 27(1), 29-41. doi:10.1016/S09218009(97)00126-2.

Mendelsohn, R., \& Olmstead, S. (2009). The Economic valuation of environmental amenities and disamenities: methods and applications. Annual Review of Environment and Resources, 34, 325-347. doi:10.1146/annurevenviron-011509-135201.

Mitchell, R., \& Carson, R. (1993). Using surveys to value public goods: the contingent valuation method. Washington, DC: Resources for the Future.

Mitchell, R.C., \& Carson R.T. (1989). Using surveys to value public goods: the contingent valuation method. Baltimore: Johns Hopkins University Press.

Morrison, M.D., Blamey, R.K., \& Bennett, J.W. (2000). Minimizing payment vehicle bias in contingent valuation studies. Environmental and Resource Economies, 16(4), 407-422. doi:10.1023/A:1008368611972.

Mulaku, G.C., \& Kariuki, L.W. (2001). Mapping and analysis of air pollution in Nairobi, Kenya. International Conference on Spatial Information for Sustainable Development. Nairobi, Kenya. Retrieved Jun, 15, 2015, from https://www.fig.net/resources/proceedings/2001/nairobi/ mulaku-kariuki-TS3-2.pdf

Odhiambo, G.O., Kinyua, A.M., Gatebe, C.K., \& Awange, J. (2010). Motor vehicles air pollution in Nairobi, Kenya. Research Journal of Environmental and Earth Sciences, 2(4), 178-187. 
Omwenga, M. (2011). Integrated transport system for liveable city environment: a case study of Nairobi Kenya. $47^{\text {th }}$ ISOCARP Congress. Retrieved Jun, 15, 2015, from http:// www.isocarp.net/data/case_studies/2022.pdf

Ryan, M., Scott, D.A., \& Donaldson, C. (2004). Valuing health care using willingness to pay: a comparison of the payment card and dichotomous choice methods. Journal of Health Economics, 23(2), 237-258. doi:10.1016/j. jhealeco.2003.09.003

Sayadi, S., Gonzalez-Roa, M.C., \& Calatrava-Requena, J. (2009). Public preferences for landscape features: the case of agricultural landscape in mountainous Mediterranean areas. Land Use Policy, 26(2), 334-344. doi:10.1016/j. landusepol.2008.04.003.

Strazzera, E., Genius, M., Scarpa, R., \& Hutchinson, G. (2003). The effect of protest votes on the estimates of WTP for use values of recreational sites. Environmental and Resource Economics, 25(4), 461-476. doi:10.1023/A:1025098431440.

Venkatachalam, L. (2004). The contingent valuation method: a review. Environmental Impact Assessment Review, 24(1), 89-124. doi:10.1016/S0195-9255(03)00138-0.

Vliet, E.D.S., \& Kinney, P.L. (2007). Impacts of roadway emissions on urban particulate matter concentrations in sub-Saharan Africa: new evidence from Nairobi, Kenya. Environmental Research Letters, 2(4), 1-6. doi:10.1088/17489326/2/4/045028.

Wang, H., \& Whittington, D. (2000). Willingness to pay for air quality improvement in Sofia, Bulgaria. World Bank Policy Research Working Paper No 2280. Washington, DC: World Bank.
Wang, H., \& Whittington, D. (2005). Measuring individuals' valuation distributions using a stochastic payment card approach. Ecological Economics, 55(2), 143-154. doi:10.1016/j.ecolecon.2004.11.011.

Wang, X.J., Zhang, W., Li, Y., Yang, K.Z., \& Bai, M. (2006). Air quality improvement estimation and assessment using contingent valuation method: a case study in Beijing. Environmental Monitoring and Assessment, 120(1), 153168. doi:10.1007/s10661-005-9054-z.

Welsh, M.P., \& Poe, G.L. (1998). Elicitation effects in contingent valuation: comparisons to a multiple bounded discrete choice approach. Journal of Environmental Economics and Management, 36(2), 170-85. doi:10.1006/ jeem.1998.1043.

White, P.C.L., Bennett, A.C., \& Hayes, E.J.V. (2001). The use of willingness-to-pay approaches in mammal conservation. Mammal Review, 31(2), 151-167. doi:10.1046/ j.1365-2907.2001.00083.x.

Whitehead, J., Blomquist, G., Ready, R., \& Huang, J. (1998). Construct validity of dichotomous choice contingent valuation questions. Environmental and Resource Economics, 11(1), 107-116. doi:10.1023/A:1008231430184.

WHO. (2006). Air Quality Guidelines: Global Update 2005. Geneva: World Health Organization. Retrieved Jun, 15, 2015, from http://www.who.int/phe/health_topics/outdoorair/outdoorair_aqg/en/

\section{VREDNOVANJE ISKAZANIH PREFERENCIJA ZA UNAPREĐENJE KVALITETA VAZDUHA U GRADU NAJROBI U KENIJI}

\section{Rezime:}

U ovom istraživanju koristi se metod uslovnog vrednovanja (CV) kako bi se ispitale preferencije/stavovi ispitanika vezano za efikasnije upravljanje kvalitetom vazduha kroz smanjenje emisija gasova iz motornih vozila u gradu Najrobi u Keniji. Sistem platne kartice (PC) kao poboljšanji oblik upitnika olakšava proces vrednovanja stavova ispitanika u cilju određivanja medijane i srednje vrednosti koju su ispitanici voljni da plate kako bi doprineli poboljšanju kvaliteta vazduha $\mathrm{u}$ gradu. Primenom regresione analize ustanovljeno je da su ispitanici spremni da plate Kshs. 396.57 (\$4.67) i srednju vrednost od Kshs. 244.94 (\$2.88) kako bi se poboljšao kvalitet vazduha u gradu. Primetno je da su ove vrednosti u porastu kod pripadnika muške populacije, osoba sa većim primanjima, izvesnim prihodima na duži vremenski period i osoba koje žive u urbanom području, dok njihova vrednost opada sa godinama, udaljenošću od obližnjih puteva, i upotrebom motornih vozila. Generalno posmatrano, ovo istraživanje ukazuje na ogromnu podršku javnosti kada je reč o unapređenju kvaliteta vazduha u gradu, što je od presudnog značaja za efikasan razvoj i sprovođenje programa upravljanja kvalitetom vazduha.

\author{
Ključne reči: \\ kontigentno (uslovno) \\ vrednovanje, \\ spremnost za plaćanje (WTP), \\ sistem platne kartice, \\ kvalitet vazduha, \\ Najrobi.
}

Received: September 9, 2015. Correction: October 2, 2015. Accepted: October 14, 2015. 